\title{
LANGUAGE AND COMMUNICATION MEDIA
}

DOI https://doi.org/10.30525/978-9934-26-073-5-2-38

\section{ОСОБЛИВОСТІ ПРИВАТНОЇ ЕЛЕКТРОННОЇ НІМЕЦЬКОМОВНОЇ КОМУНІКАЦЇ̈}

\author{
Беззубова О. О. \\ кандидат філологічних наук, дочент, \\ доцент кафедри теорії, практики та перекладу німецької мови \\ Національного технічного університету Украӥни \\ «Київський політехнічний інститут імені Ігоря Сікорського» \\ м. Київ, Украӥна
}

Життєдіяльність суспільства XXI століття невід'ємно пов'язана 3 новітніми комунікаційними технологіями та електронною комунікацією. Електронна комунікація охоплює спілкування, що здійснюється за допомогою Інтернету та інших комунікаційних платформ, наприклад, мобільної телефонії [1]. Електронній комунікації відводиться роль відновлення балансу між розумом і почуттями людей, втраченими протягом історії людства, зміною засобів відтворення навколишнього світу [3]. Нові форми електронної комунікації Facebook, WhatsApp, Facebook Messenger, Instagram, QQ, Tik Tok, Twitter, LinkedIn 3 відповідно найбільшою кількістю зареєстрованих користувачів різних вікових категорій [8] забезпечують комунікативні потреби сучасного суспільства.

Електронна, віртуальна або Інтернет-комунікація виступає об'єктом нового лінгвістичного напрямку, що аналізує лінгвістику Інтернету [1]. Електронна комунікація змінила фундаментальну сутність міжперсональної й соціальних комунікацій та зумовила різноманітні процеси на всіх рівнях мови. Предметом міждисциплінарних досліджень є вплив електронної комунікації на суспільство, культуру та мову.

Телеграма як канал і форма технічно-опосередкованої передачі даних на великі відстані між суб'єктами інформаційних відносин представляє прототип електронної комунікації. Реалізуючи прагнення сучасних людей до можливості економічно вигідного спілкування в будь-який час доби та з будь-якої точки планети без залежності від місцезнаходження «співрозмовника», науково-технічний прогрес викликав до життя унікальний засіб комунікації, який об'єднує в собі функції телефону 148 
3 його можливістю спілкування в режимі реального часу та телеграми 3 іiі письмовою стислою формою викладу [1, с. 20]. Смс-повідомлення $\epsilon$ однією із форм електронної комунікації, яка дозволяє передавати інформацію та вирішувати численні комунікативні завдання, що зумовило масовий та приватний характер смс-повідомлень. Наприклад, масове смс-повідомлення із пропозицією долучитися до програми лояльності: Willkommen im Le Club AccorHotels-Programm. Ihre Mitgliedsnummer lautet 30810313481341BP. Schließen Sie Ihre Anmeldung hier ab: http://bit.ly/32hEOpT

Адресант масових смс-повідомлень - це соціальний продуцент [7], який звертається до реципієнта від імені суспільної структури - фірми, підприємства та громадської організації, репрезентує певні соціальні, групові чи корпоративні інтереси, надає інформацію різного характеру та пропонує в формі комерційної, політичної або соціальної смс-реклами різноманітні послуги, що $є$ ефективним засобом маркетингової політики.

Смс-повідомлення стрімко перетворилися на релевантну складову міжперсонального спілкування. Приватними смс-повідомленнями обмінюються з товаришами, друзями/ подругами, коханими, членами сім’ї, колегами і т. д. Наприклад, смс-повідомлення, надіслане колезі: ich machs bis heute abend ok?

Смс-повідомлення в специфічних електронних умовах існує як особливий мовленнєвий твір, який позначають терміном «стислий текст» [5]. В умовах становлення комунікативного суспільства і прискорення темпу життя стислі тексти набувають все більшого значення в усіх сферах. Під поняттям стислий текст розуміють повідомлення, яке об'єктивоване подібно будь-якому іншому тексту в письмовій формі, побудоване шляхом скорочення повного тексту або створене як первісно коротке, призначене при необхідності для подальшого розгортання в більш об’ємний текст [6, с. 286]. Наприклад, два послідовні повідомлення, якими адресант стисло і експресивно описує ситуацію в Німеччині, викликану пандемією COVID-19:

12:33 Wir haben seit November mehr oder weniger lockdown.

\section{2:33 Nervt}

В зв'язку 3 розповсюдженням месенджерів служба коротких повідомлень з 2015 року почала втрачати лідируючу позицію. Однак функціональність смс-комунікації 3 можливістю швидко досягнути адресата, іiі інтерактивністю, яка за певних об'єктивних умов дозволяє швидко здійснити комунікативний акт, i можливістю задовольнити базові потреби в спілкуванні забезпечують важливе місце смсповідомлень в комунікаційній системі інформаційного суспільства. 
Наприклад, смс-повідомлення, яким адресант скасовує заплановану зустріч із адресатом: 09:10 Guten Morgen, es sieht nicht gut aus. Ich muss leider hier bleiben. Danke für alles. Ich melde mich. Mit lieben Grüßen

Міжперсональна комунікація характеризується соціальною масштабністю і актуалізується все частіше в електронному просторі. На сьогодні в міжперсональній німецькомовній комунікації превалює спілкування у месенджері WhatsApp, що наслідує принципи смс-комунікації. Наприклад, короткий діалогічний комунікативний акт, що відбиває деякі реалії життя у час пандемії - погіршення фінансового стану та обмежені можливості подорожувати:

- Das Virus hat uns Alle erwischt, Alle haben weniger als vorher.

Das ist schade, wir müssen erst mal abwarten ob das Reisen funktioniert

- Ja, genau

В процесі спілкування здійснюється обмін видами діяльності, їхніми способами та результатами, уявленнями, ідеями, установками, інтересами, почуттями і т. д. [4]. У приватній електронній комунікації відбувається ретрансляція становлення та екзистенції індивіда в соціумі. Тексти приватних електронних повідомлень мають соціальну природу, відбиваючи всі актуальні теми для мовців.

Винайдення нових засобів зв'язку та передачі даних, їхнє постійне удосконалення продукують широкі можливості спілкування. Подальший функціональний аналіз німецькомовної реклами в електронному просторі відкриває цікаві перспективи дослідження електронної комунікації.

\section{Література:}

1. Венедиктова Ю.Е. Смс-сообщения: опыт типологического исследования (на материале английского и русского языков): автореф. дис. на соискание уч. степени канд. филол. наук: 10.02.20. Москва, 2011. $22 \mathrm{c}$.

2. Горошко Е.И. Теоретический анализ Интернет-жанров: к описанию проблемной области. Жанры речи: сб. науч. тр. / под ред. В.В. Дементьева. Вып. 4. Саратов, 2007. С. 111-127.

3. Моісєєва Н. Електронна епоха соціальних комунікацій: структурно-діяльнісні трансформації. Вісник Книжкової палати. № 3. 2014. C. 49. URL: http://www.irbis-nbuv.gov.ua/cgi-bin/irbis_nbuv/ cgiirbis_64.exe?C21COM=2\&I21DBN=UJRN\&P21DBN=UJRN\&IMAGE_ FILE_DOWNLOAD=1\&Image_file_name=PDF/vkp_2014_3_16.pdf （дата звернення: 08.03.2020). 
4. Олешков М.Ю. Моделирование коммуникативного процесса: монография. Нижний Тагил: Нижнетагильская гос. соц.-пед. академия [и др.]., 2006. 336 с. URL: http://rudocs.exdat.com/docs/index-48183.html (дата звернення: 18.03.2020).

5. Панченко Е.И. Лингвистика сжатого текста (на материале современного русского языка): дис. ... д-ра филол. наук: 10.02.02. Донецк, 1998. 380 с.

6. Панченко Е.И. Сжатый текст: текст современности и будущего. Русский язык: исторические судьбы и современность: сборник тезисов I Международного конгресса исследователей русского языка. М., 2001. C. $286-287$.

7. Солганик Г.Я. Автор как стилеобразующая категория публицистического текста. Вестник Московского университета. Серия 10. Журналистика. № 3. Москва: Изд-во МГУ, 2001. С. 75.

8. Die wichtigsten Social Media Trends für 2020. URL: https://www.wuv.de/tech/die_wichtigsten_social_media_trends_fuer_ 2020 (дата звернення: 18.01.2020).

DOI https://doi.org/10.30525/978-9934-26-073-5-2-39

\title{
СЕМАНТИЧНІ ІННОВАЦЙНІ ОДИНИЦІ В ЗАГОЛОВКАХ ПЕРІОДИЧНИХ УКРАЇНСЬКОМОВНИХ ІНТЕРНЕТ-ВИДАНЬ
}

\author{
Бойчук М. В. \\ кандидат філологічних наук, \\ дочент кафедри права \\ Івано-Франківської філії Відкритого міжнародного університету \\ розвитку людини «Україна»
}

\section{Бойчук В. М.}

кандидат філологічних наук, дочент, завідувач кафедри сочіально-гуманітарних дисциплін Прикарпатського факультету Начіональної академії внутрішніх справ м. Івано-Франківськ, Україна

Динамічні зміни в лексиці сучасної української мови зумовлені різними чинниками, зокрема й активними процесами у межах лінгвосистеми з огляду на розширення функціоналу мови. Результатами перетворень значною мірою $є$ семантичні трансформації лексичного 